\title{
Reverse Mergers: The Way Forward
}

\author{
Dr. Samiksha Ojha, Richa Maheshwari, Star Jain \\ Associate Professor, International Management Institute, New Delhi \\ PGDM, International Management Institute, New Delhi \\ PGDM, International Management Institute, New Delhi
}

\begin{abstract}
The paper explains the mechanism of Reverse Mergers in great detail. It deals with an explanation of Reverse Mergers, their advantages over traditional IPO route, the actual process involved in a reverse merger and SWOT analysis (Strengths, Weaknesses, Opportunities and Threats) of this method. Further, the paper discusses the global scenario with respect to this mechanism, particularly in countries like United States and China where it is highly preferred for public listing.

The paper also details this concept with respect to its acceptance in our country, India, where traditional methods like IPOs are losing relevance and newer faster methods for public listing and fund raising are gaining importance with each passing year. For greater understanding, some case studies have been used spanning various companies which have taken this route for public listing and have reaped great benefits from it. The paper also highlights the ill effects attached with Reverse Mergers if not done properly and without enough checks and audits.
\end{abstract}

\section{Introduction}

With the inception of the idea of the world as a "Global village" and Globalization being the buzzword, new practices are being adopted and accepted by the financial world so as to save time; increase the existing benefits and expedite the processes involved in various operations.

Reverse Merger is the aftermath of such innovative practice adoption over the already existing traditional IPO route to become a public listed company. It helps a private company to get rid of the hassles involved in the IPO process and speeds up the process for Public listing. The main difference between an IPO and a Reverse Merger is that an IPO allows a company to go public and also helps it to raise capital; whereas Reverse merger allows it only to go public (Augusto Arellano-Ostoa and Sandro Brusco). However, a reverse merger is preferred nowadays by a large number of small firms who are in a hurry to get listed without much effort and lengthy listing requirements involved in IPOs.

A reverse merger is often suggested as the best option to provide greater access to the capital markets, increase the company's visibility in the investment community, and offer the opportunity to utilize its stock to make acquisitions (JAMES MOLLOY and MICHAEL FUNG). Time saving, avoidance of the initial lengthy listing requirements, fast fund raising, cost savings are some of the positives involved with this method.

This method is basically a stock swap technique through which a privately owned company is acquired by a defunct public company. The public company is either a company that is not involved in real activities anymore or a SPAC (Special Purpose Acquisition Corporation or a shell company) created specifically for the purpose of Reverse Merger (Augusto Arellano-Ostoa and Sandro Brusco).

The final result is that the privately held company becomes a public listed company in a very short period of time (Augusto Arellano-Ostoa and Sandro Brusco). This further creates an opportunity for the new public listed company to generate finances using PIPE (Private Investment in Public Equity) financing methods, FPOs (Further Public Offerings) etc.

\section{Public Shell Company}

- A registrant with no or nominal operations and either no or nominal assets, assets consisting solely of cash and cash equivalents and generally no liabilities (Barry I. Grossman, Esq. Ellenoff Grossman \& Schole LLP).

- It serves as a vehicle for business transactions like being used for Reverse Mergers etc. ${ }^{[2]}$ 


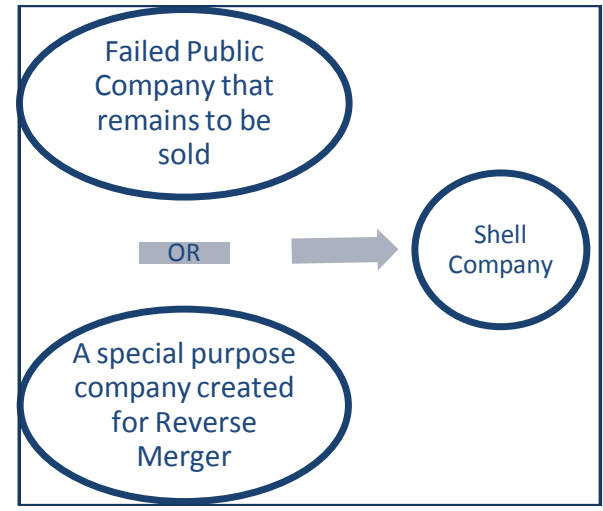

Figure 1

This phenomenon has also gained a lot of importance in some of the fast emerging economies like China where a good number of companies are taking this route to get them listed in foreign markets. This idea of one country's company trying to get listed on the stock exchange of some other country by merging with a public listed company of that country is known as Cross Border Reverse Merger. This is being used by Chinese firms to gain access to the US stock exchange. Here, the Chinese private company tries to adopt the US-state level corporate law and also uses this strategy to get quick financing (Jordan Siegel, Yanbo Wang).

It is worth noting that the name "reverse" comes from the fact that although the shell company acquires the private company, it is the private company that survives (Augusto Arellano-Ostoa and Sandro Brusco).

Reverse Mergers do have some disadvantages too. If not properly audited by good and credible auditing agencies, various conflicts of interests might arise and chances of fraud cases cropping up increase. All this might happen because the shell company might have a hidden liability involved which might come to the fore after the merger takes place (Augusto Arellano-Ostoa and Sandro Brusco). Therefore, the identification of a good and clean shell company is a must for an effective Reverse Merger.

The paper explains the mechanism of reverse merger in a nutshell. In further sections we have identified the positives and negatives associated with reverse merger through detailed S.W.O.T. analysis. For a clear understanding of the concept at Global and Indian level, we have taken up various live cases at both the levels and explained the future aspects and some of the shortcomings through their study and analysis.

\section{Literature Review}

According to Augusto Arellano-Ostoa and Sandro Brusco(May 2002), Reverse Mergers are an efficient way to go public and are preferred under certain conditions by low type firms over an IPO which are costlier and are preferred by certain high-type firms. Here, a three period model has been devised to compare the costs involved in an IPO and a Reverse merger.

According to William K. Sjostrom, Jr. (2008), the idea that Reverse Mergers are quicker and cheaper method to go public has been construed to be misleading and arguments have been presented accordingly with respect to the IPO. The paper brings forth the principal features of reverse mergers and talks about the deal structure and legal compliance involved in the process.

According to James Molly, there are only a few companies that succeed in creating long-term shareholder value through the reverse merger process. An argument has been presented that the majority of the benefits ascribed to the reverse merger process are beneficial to getting to the public markets quickly, but very few translate into benefits for the shareholders of the newly formed public company (JAMES MOLLOY and MICHAEL FUNG).

According to Jordan Siegel and Yanbo Wang (December, 2012), a study of a set of non-U.S. companies that have used a reverse merger into the U.S. as a means to adopt U.S. corporate law has been done. The study shows that many of the companies which have entered the US markets lately have exploited weak U.S. cross border laws coercing the SEC to lay down stringent norms to Cross border Reverse Mergers.

According to David N. Feldman, Reverse Mergers are gradually taking the space earlier occupied by IPOs due to the complexities and slowness of the IPO method for going public. If done with sufficient checks, the ill effects associated with Reverse Mergers could be mitigated.

Kimberley C. Gleason, Jain and Rosenthal have analyzed the type of companies and their state before they go for Reverse Mergers over the traditional IPO route. The finding says that firms that go for contemporary measures are less profitable at the time of going public as compared to contemporaneously issued IPO firms of comparable size.

Floros and Travis R. Sapp(2011) have analyzed the Shell companies which have been a part of Reverse Mergers and also a critical analysis have been done answering questions like the value derived to a private 
company from a shell firm, benefits to investors from Reverse Mergers, type of private firms involved in Reverse Mergers etc.

According to Jindra, Voetmann and Walkling (Oct, 2012), a larger number of Chinese corporations have used Reverse Mergers to get themselves listed on the American stock exchange. A number of lawsuits have been filed against some of these firms due to ill practices which are still being dealt in the court of law.

Cornerstone Research discusses the litigations going on Chinese companies and also brings to the limelight the impact of such issues on the stock market valuation.

Blair, Poletti and Tran(Dec, 2011) talk about the tougher stand that the SEC has taken to avoid issues that have come due to Cross border Reverse mergers and to check frauds.

According to Ritter and Welch (2002), many IPO phenomena are not stationary and asymmetric information is not the primary driver of many IPO phenomena.

Sahoo and Prabina Rajib in their paper have discussed the Indian IPO market from 2002 to 2006, pricing at the time of listing and evaluation of price performance of IPOs up to a period of 36 months including the listing day. It also examines the usefulness of IPO characteristics at the time of issue to seek an explanation for the post issue price performance.

Pagano, Panetta and Zingales (Feb, 1998) provide an empirical analysis on why do companies go public. They have analyzed the IPOs by comparing the ex ante and ex post characteristics of IPOs with those of private firms,

\section{$\underline{\text { Reverse Merger: Mechanism }}{ }^{*}$}

Step 1:

Instead of hiring an underwriter to market and sell the company's share in an initial public offering $(\mathbb{P O})$, a private company works with a shell promoter to locate a non operating or SHELL PUBLIC company.

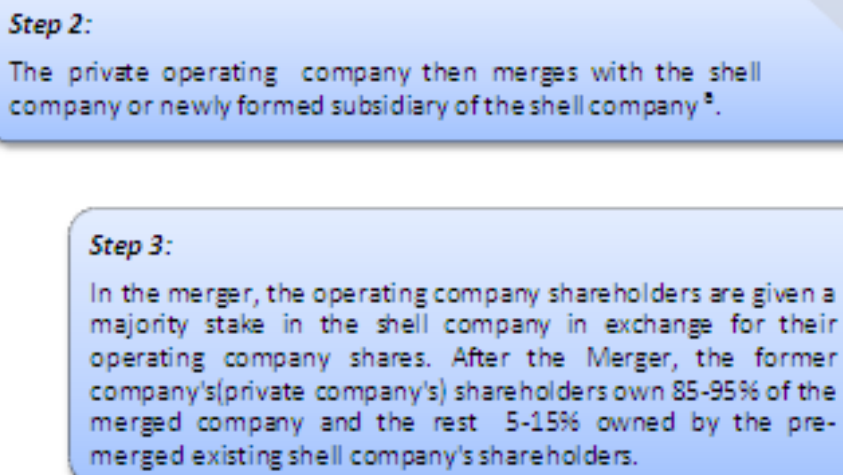




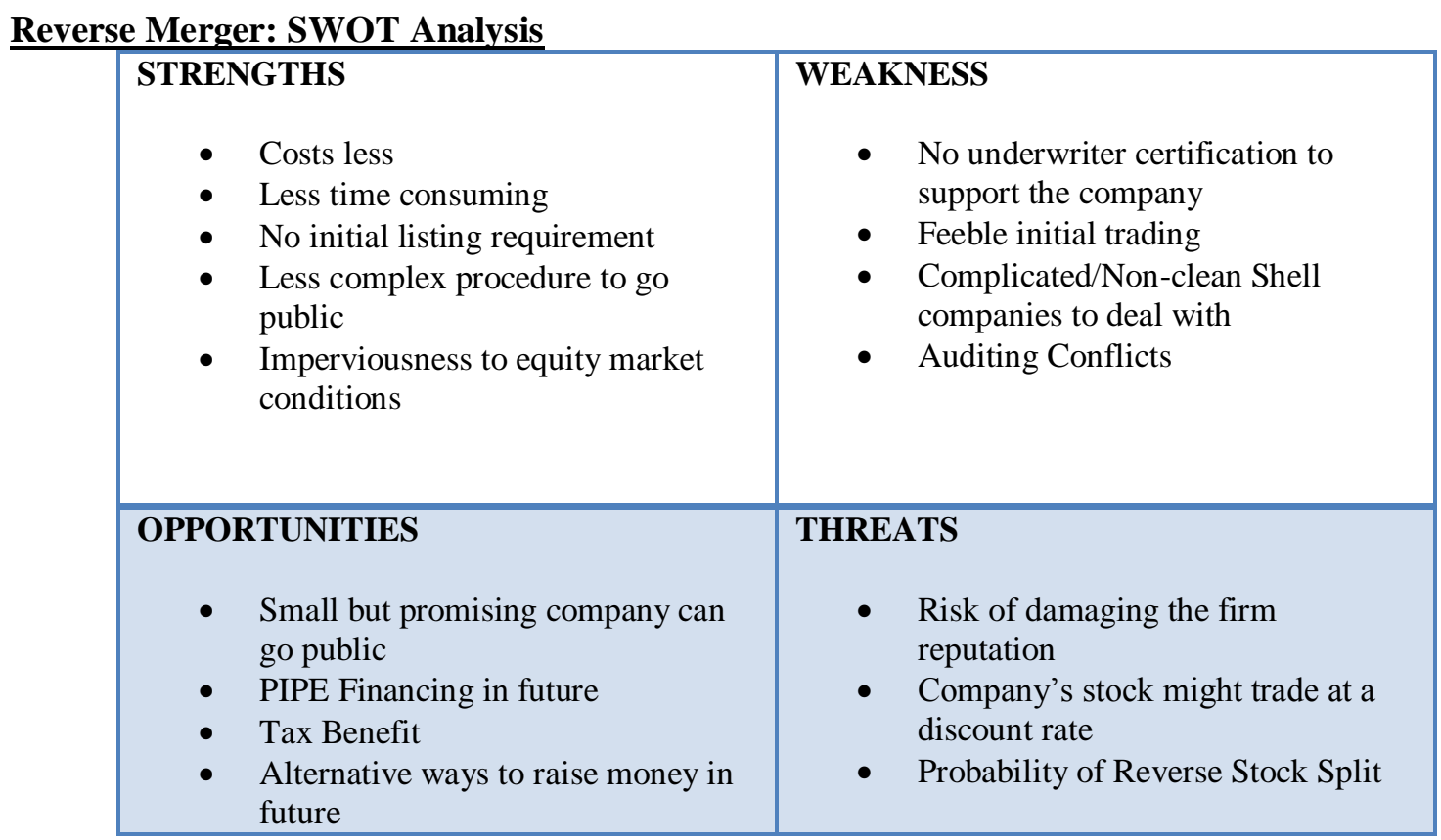

\section{STRENGTHS}

Cost and Time: The process of reverse merger costs less and depends on the cost of the shell company. The process involves less of formal procedure and therefore, can be completed for less than $\$ 2$ million in most of the cases ${ }^{[8]}$. Typically, average time taken to complete the reverse merger is $3-4$ months ${ }^{[8]}$, in some of the cases it can be completed within 30 days as it involves no registration statement and no regulating agency review.

Listing Requirements: Through reverse merger, private companies can avoid the troublesome procedure of meeting the initial listing requirements established by the regulating agencies for going public in various countries. As the public company is already listed, the private company need not bother about the listing procedure.

Market Dependency: Market conditions at the time of reverse merger play small role as there is not much trading involved immediately after the merger. The possibility of a merger being put on hold or cancelled is rare as compared to an IPO where equity market conditions and unfavorable publicity might provoke underwriters to cancel the proceedings.

\section{WEAKNESSES}

Complicated Shell: It might be possible that the private company while merging with the public company can face issues of liability lawsuits and poor record keeping. Hence, the company needs to be very careful while choosing a public company.

Feeble Trading: Initial trading of the company after the merger is very low. Companies have to work on building the stock value and increase the prospects of trading after certain period of time.

No underwriter certification: There is no underwriter approval required hence, the companies which go through reverse mergers do not receive any underwriter certificate; which might reduce a company's credibility.

Auditing Conflicts: In the case of cross border reverse mergers, especially in the case of Chinese firms; it has been found out that there have been conflicts between the auditing reports of Chinese audit firms and US audit firms which hampers the investors' interest ${ }^{[13]}$. In the past, this has led to a number of fraud cases which are still pending in the US courts.

\section{OPPORTUNITIES}

Beneficial to small companies: Small companies which are growing and need additional source of capital can go through the process of reverse merger which is faster and cheaper and does not need to meet the minimum underwriting requirements. 
Tax Benefit: As in case of Reverse merger the shell company is a public company which probably has taken a series of losses in the past. A percentage of these losses can be carried forward and applied to future income and thus after the merger, it is possible to keep a percentage of the newly formed company's profits from future taxes.

PIPE Financing ${ }^{c}$ : PIPE refers to Private Investment in Public Equity which helps a public company to get financing from small sophisticated investors. Hence, if a company goes through reverse merger, it can open its doors to PIPE financing.

Alternative Ways to raise money: Additional shares can be issued in a secondary offering. When stockholders possess warrants they have the right to purchase additional stock at a pre-determined price - the exercise of these options provides additional capital infusion into the company.

\section{THREATS}

Market Reputation: A company going public through reverse merger might run the risk of dented reputation as the market will perceive that the company failed to pass underwriter standards and is of low quality.

Discounted Stock Value: Since the company is not backed up by underwriters and is merged with a shell company hence, the stock might be traded at a lower value and company may face relative stock illiquidity.

Reverse Stock Split ${ }^{\mathrm{d}}$ : They are quite common when a company goes public through reverse merger and may lead to reduced number of tradable stocks.

\section{Reverse Merger: Global Scenario}

A good number of successful reverse mergers in the past have yielded millions of revenue for a large number of companies, particularly in countries like China, US and Canada. This has drawn the interest of large number of private companies who are looking for options to raise more money from the market. Some success stories of the past are mentioned below ${ }^{[19]}$ :

- Occidental Petroleum: In the mid 1950s, Armand Hammer invested in a shell company into which he merged Occidental Petroleum.

- Turner Broadcasting : In 1970, Ted Turner completed a reverse merger with failing Rice Broadcasting, thus emerged Turner Broadcasting

- Rare Medium: This was one of the Dot Com fallen Angels, which was merged with a marginal refrigeration company. This was a $\$ 2$ stock in 1998 which found its way over $\$ 90$ in 2000 after the merger.

- On Feb 2007, CKX, formerly Sports Entertainment, a stock trading at the 5-10 cent level, announced a reverse merger with Elvis Presley Enterprises, which controlled all the rights to Elvis Presley's estate. The stock price rose sharply after the merger (Sandeep Poddar).

After the success of some of the above mentioned companies, this mechanism is gaining importance with each passing day. The facts justify this well: Closed Reverse Merger totalled 46 in 2003, 168 in 2004, and 179 in 2005 alone in US and an ever increasing trend thereafter (WILLIAM K. SJOSTROM, JR.).

In the recent years, it has been observed that companies and investors are taking these different paths to raise funds from the public. There has been a discernible decline in their interest towards the time consuming IPOs. Bankers say raising funds through IPOs is not easy as it involves lengthy processes, huge costs, valuation mismatches due to delays in regulatory approvals, apart from strict due diligence by merchant bankers. Hence, companies are opting for quicker routes for funds ${ }^{[3]}$.

Case: Reverse Merger between Actinium Pharmaceuticals Inc. and Cactus Ventures Inc.

Public Company: Cactus Ventures Inc.

Private Company: Actinium Pharmaceuticals Inc.As per a share exchange agreement dated December 28, 2012, Actinium Pharmaceuticals Inc., a New York based Biopharmaceutical Company went public via a reverse merger with Cactus Ventures, Inc., which was a public company.

After the merger, former shareholders of Actinium became the controlling shareholders of the public Company. On the closing of the share exchange approximately $21 \%$ of Actinium's issued and outstanding shares were exchanged for 4,309,015 shares of the Company's common stock ${ }^{[25]}$. The Company's stock would currently

\footnotetext{
${ }^{\mathrm{c}}$ For more details: see James R. Tanenbaum \& Anna T. Pinedo, The Law: Legal and Regulatory Framework, in PIPES: a guide to private investments in public equity revised and updated edition 77, 93 (2006).

${ }^{\mathrm{d}}$ For more details on stock split refer: Return Performance Surrounding Reverse Stock Splits: Can Investors

Profit?: April Klein, James Rosenfeld, X. Jenny Tucker, www.investopedia.com
} 
trade under the name Cactus Ventures, Inc. until such time as the intended name change to Actinium Pharmaceuticals, Inc. takes effect ${ }^{[25]}$.

The Company would continue to exchange its shares of common stock for shares of Actinium held by the remaining Actinium shareholders and would urge existing Actinium shareholders to do so as quickly as possible.

After the closing of the share exchange, the Company would continue the Offering on the same terms on a pro-forma basis with the common shares offered at $\$ 1.65$ per share, the 120 day warrants exercise price at $\$ 1.65$ per share and the 5 year warrants exercise price at $\$ 2.47$ per share ${ }^{[25]}$. Investors in the Offering would receive securities of the Company, the public company, and not Actinium. The newly formed Company is authorized to sell up to $\$ 15$ million in gross proceeds in the Offering ${ }^{[25]}$.

The above example clearly elucidates the impact of reverse merger and some of the activities that take place after it in great detail.

\section{Cross Border Reverse Merger (China and U.S. Story):}

The Chinese companies have taken the path of cross border reverse merger for fast public listing in the United States. The Chinese private companies typically acquire the shell companies in the US which are publicly traded. After the merger, the American board resigns; the Chinese board takes over, changes the company's name and issues new stock to hedge funds and other new investors, raising millions of dollars in fresh capital (Augusto Arellano-Ostoa and Sandro Brusco).

\section{Reasons for inclination towards Cross Border reverse mergers in China}

1. Reverse mergers are faster as compared to other conventional sources like IPOs to get listed and to generate funds.

2. Small companies in the country's rust belt or in industries that aren't attractive are unlikely to draw venture capital or investments. So, this route to generate funds becomes all the more important.

3. Moreover, there is a 2 year wait for a listing on the Shanghai or Shenzhen stock exchanges.

4. Also, there is less interference from investors in private companies so, taking the decision for a reverse merger for them is relatively easy.

Reverse mergers have proved very popular with foreign companies to list in the US market. The Public Company Oversight Board (PCAOB), which oversees auditing forms of public companies, discerned that of the 603 reverse mergers between Jan, 2007 and Mar, 2010, 159 were Chinese companies, about 26\% (David N. Feldman).

Some of the successful examples include:

- Sinovac Biotech Ltd. (SVA), a respected Beijing-based maker of vaccines, executed a reverse merger in 2003 and subsequently raised 12 million dollars and is currently a registered company on NASDAQ global markets (Sandeep Poddar).

- GLOBAL SOURCES went for a reverse merger with asset shell FAIRCHILD. After which it had made market capitalization of $\$ 430$ million, $\$ 50 \mathrm{mn}$ in cash, no debt and \$22 mn in EBITDA (Sandeep Poddar).

But recently some investigations have helped in disclosing a number of fraud cases of various kinds as far as Chinese reverse mergers are concerned. Some of these are still being investigated and some have been dismissed (David N. Feldman). These fraud cases has led to the SEC (Securities and Exchange Commission of United States) to begin investigating not only these companies but also the entire reverse merger industry, including accountants, attorneys and Investment banks highlighting the risks involved and the ill effects of reverse mergers if not done with due diligence. (David N. Feldman)

\section{A few fraud reverse merger cases are mentioned below:}

A leading offset printing equipment supplier Duoyuan Printing Inc was created through a reverse merger in 2006 with a Wyoming incorporated shell. For 4 years, things were going fine until Deloitte was assigned the role of auditing. It uncovered several financial irregularities due to the merger and therefore, was delisted on April 4, 2011 from NYSE (New York Stock Exchange) ${ }^{[23]}$.

Another company, China MediaExpress was listed in the U.S. stock exchange following a 2009 takeover of TM Entertainment \& Media Inc., a so-called blank check company with no operations of its own(a shell company). This reverse merger was also caught up in a fraud which led to its downfall ${ }^{[24]}$.

All these cases and many more highlighted the need for stringent norms and stricter regulations thereby making the role of SEC more relevant. Hence, On November 8, 2011, the SEC approved new listing standards making it more difficult for a company effecting a reverse merger to list on any of the three major U.S. stock exchangesNasdaq, NYSE, and NYSE Amex (Katherine J. Blair, Thomas J. Poletti, Anh Q. Tran). 
As per the new rules, companies are now required to comply with more stringent listing requirements while going public through a reverse merger transaction. A reverse merger company now must complete a one-year "seasoning period" of trading its securities on a U.S. over-the-counter market or another regulated exchange before getting listed. During the seasoning period, timely filing of each required public periodic report must be done by the company and it needs to maintain the requisite minimum share price for a sustained period, and for at least 30 of the 60 trading days, immediately prior to its listing application and the exchange's decision to list $^{[18]}$.

\section{Reverse Mergers: Indian Scenario}

The concept of reverse merger is also gaining momentum in India. Existing foreign companies and their subsidiary are trying to induce in the concept of reverse merger in India by following the same path. The recent Reverse merger of Hardcastle restaurants(master franchisee for south and west India operations of burger chain McDonald's Corp. which operates 148 restaurants in India) with Westlife Development Ltd in India Stands testimony to the fact that Reverse Mergers are gaining importance in India.

A number of laws are also being tweaked in India so as to ensure safety for the investors involved in reverse merger deals. The Companies bill, 2011, has provided an exit option for minority shareholders of a listed company in a reverse merger. The law in force at present does not provide for this. "If shareholders of the transfer or company decide to opt out of the transferee company, provision shall be made for payment of the value of shares held by them and other benefits, in accordance with a pre-determined price formula or after a valuation is made," says the new Bill ${ }^{[7]}$. All these changes try to curb in the loopholes involved in reverse mergers and will help in preventing frauds. Also, it would empower the investors to invest more in reverse merger companies.

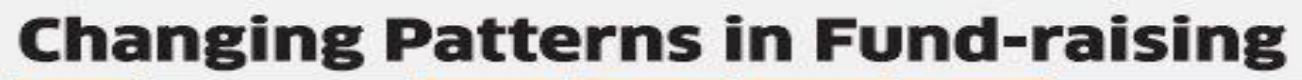

\begin{tabular}{|c|c|c|c|c|c|}
\hline when & Ines & mese & 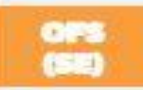 & $c$ & How \\
\hline 2012 & 6,938 & 0 & 23,769 & 4,705 & 36,253 \\
\hline 2011 & 5,966 & 8,055 & 0 & 3.459 & 17,480 \\
\hline 2010 & 37,535 & 31,577 & 0 & 27,423 & 99,022 \\
\hline 2009 & 19,544 & 23 & 0 & 38,676 & 58,243 \\
\hline 2008 & 16,904 & 23 & 0 & 3,586 & 20,513 \\
\hline 2007 & 34,179 & 10,962 & 0 & 23,400 & 68,542 \\
\hline 2006 & 19,852 & 4,817 & 0 & 3,935 & 28,604 \\
\hline 2005 & 9,990 & 12,764 & 0 & 0 & 22,754 \\
\hline 2004 & 13,121 & 17,389 & 0 & $\overline{0}$ & 30,511 \\
\hline
\end{tabular}

Figure 2

From Figure 2, it can be observed that there has been a drastic decline in the funds raised through traditional IPOs, which have proved to be very costly and time consuming. This clearly shows that companies and investors are looking for alternative ways for public listing and fund raising, thus showing the potential of reverse mergers in India.

Case study

\section{McDonalds franchisee Hardcastle Went Public through Westlife Development Limited}

Private Company: Hardcastle Restaurants Private Limited (HRPL)

Public Listed Company: Westlife Development Ltd.

Hardcastle Restaurants Private Limited (HRPL), master franchisee for south and west India operations of burger chain McDonald's Corp, merged with its parent Westlife Development Ltd. which is listed on Bombay Stock Exchange in the month of December 2012.

The financial performance of WestLife Development (Shell Company) for the year 2011-2012 ending March 2012 is ${ }^{[11]}$

- Revenue of Rs. 12.2 million

- $\quad$ EBITDA of Rs. 4.36 million

- Net loss after Tax of Rs. 9.94 million

The company was in loss and its stock was rarely traded on Bombay stock Exchange, which resulted in low share price. 
The financial performance HRPL for financial year 2011-12 ending march 31, $2012^{[11]}$ :

- $\quad$ Revenue increases $\mathbf{4 4 \%}$ to $5444.6 \mathrm{mn}$

- $\quad$ EBIDTA rises $69 \%$ to $672.4 \mathrm{mn}$

- Net profits increase by $\mathbf{1 2 6 \%}$ to $425.1 \mathrm{mn}$

The franchisee operates 148 restaurants across western and southern India, has been growing at a compounded annual growth rate of 22.3 per cent over the last three years. It serves over 165 million customers across India [11].

After the merger, HRPL has become a wholly owned unit of Bombay Stock Exchange-listed Westlife Development, giving investors a chance to participate in the growth of McDonald's in India. In the process, poorly performing Westlife would merge with HRPL and the company is listed in the name of "Westlife Developments Ltd.". Its strategy after the merger has been to increase McDonald's retail footprint to strengthen its presence in the existing market and enter newer ones.

The process was quite simple and took very less time to materialize. Little-known Westlife Developments rose up the stock market overnight, with its shares rising $75 \%$ in virtually three trading days after McDonalds' franchisee Hardcastle Restaurants became its direct subsidiary.

Shares of Westlife Developments closed at Rs 153.90 on the Bombay Stock Exchange three days after the merger, up from Rs 86.20 on the day of merger ${ }^{[12]}$

The above example shows that inspite of the risk averse attitude of Indians towards newer methods, they are being brought to the financial arena due to the presence of the foreign companies here, who are using methods like reverse mergers to gain great benefits from it. The market capitalization of the company above almost doubled after the merger due to improved sentiments providing insights of how advantageous such methods could be for a country like India in the future. Here, it would be imperative to mention that India has stricter norms and policies for market regulations compared to other countries making it all the more a suitable location for Reverse Mergers which could be harmful if not done with cleaner audits. The new Companies bill has also ensured that shareholders rights are protected to the fullest.

In the near future, we can expect that mechanisms like reverse mergers would be embraced by the Indians due to the inherent advantages attached and also the suitability of such methods because of a good corporate law in the country.

\section{Conclusion}

Seeing the importance Reverse Mergers are getting in the recent years, it is clear that in the time to come, it would become one of the most preferred methods of public listing all over the world.

Both developed and developing countries are realizing that reducing time and cost are the best ways for companies to gain competitive advantage over their competitors, all the more highlighting the importance of such methods which serve both the objectives comprehensively.

Through this paper, we have tried to analyze the concept of Reverse Mergers in a holistic way by discussing the strengths and weaknesses attached the acceptability of it in various economies, the present status and developments associated in great detail.

However, there are certain shortcomings associated with Reverse Mergers when not done with proper analysis, checks and audits. A lot of fraud cases have also come up majorly involving Chinese private companies who have tried to get themselves listed on the US stock exchange. More stringent laws have been imposed by SEC to prevent such frauds and also to ensure that this methodology proves to be a boon rather than a curse.

All in all, a country with a good corporate law with greater control and more credible auditing agencies is the best place where the benefits of Reverse mergers can be enjoyed to the fullest.

\section{References}

[1] Full Speed Reverse! The Reverse Merger: Backing into Wall Street's Worst Idea By JAMES MOLLOY (Associate) and MICHAEL FUNG (CFA) Mirus' Technology Group.

2] http://en.wikipedia.org/wiki/Shell_corporation: details about a shell company

[3] http://economictimes.indiatimes.com/markets/ipos/fpos/rights-issues/costly-ipos-may-lose-out-to-hassle-free-reversemergers/articleshow/17946104.cms : article revealing the benefits of reverse mergers

[4] UNDERSTANDING REVERSE MERGERS: A FIRST APPROACH , By: Augusto Arellano-Ostoa and Sandro Brusco

[5] http://www.siliconindia.com/shownews/Reverse merger concept may find takers in India -nid-38218-cid-3.html

[6] COMMENTS ON SEASONING OF REVERSE MERGER COMPANIES BEFORE UPLISTING TO NATIONAL SECURITIES EXCHANGES --David N. Feldman

[7] http://www.business-standard.com/article/markets/reverse-mergers-exit-option-in-new-cos-bill-111122100059 1.html

[8] http://www.investopedia.com/articles/stocks/09/introduction-reverse-mergers.asp\#ixzz2J6aUMeMI

[9] http://www.business-standard.com/india/news/reverse-mergers-exit-option-in-new-cos-bill/459179/----------------IMP : Future Prospects of reverse mergers

[10] http://hkcompanylawblog.com/2012/11/14/uncover-the-reverse-merger-game/ 
[11] http://www.moneycontrol.com/mccode/news/article/article_pdf.php?autono=792115\&num=0

[12] http://www.dnaindia.com/money/report_someones-lovin-it-westlifes-merger-with-hardcastle-that-is_1776402

[13] http://www.forbes.com/sites/francinemckenna/2011/03/15/chinese-reverse-merger-companies-the-auditor-angle/

[14] Paper on "The Truth About Reverse Mergers" By: WILLIAM K. SJOSTROM, JR.

[15] http://www.nj.com/business/index.ssf/2012/12/knight capital getco virtu tak.html

[16] http://www.bloomberg.com/news/2012-11-28/getco-proposes-buying-knight-capital-at-3-50-a-share.html

[17] 'Tis the Season: SEC Approves Tougher "Seasoning" Requirements for Reverse Merger Companies Looking to List on a Major Exchange By Katherine J. Blair, Thomas J. Poletti, Anh Q. Tran

[18] http://www.sec.gov/news/press/2011/2011-235.htm

[19] http://www.reversemergers.net/advantages.html

[20] Alternative Public Offerings: What companies need to know by Barry I. Grossman, Esq. Ellenoff Grossman \& Schole LLP

[21] HBR: Cross-Border Reverse Mergers: Causes and Consequences; By: Jordan Siegel, Yanbo Wang

[22] Europlus Capital Limited: A study on Reverse Merger, by Sandeep Poddar

[23] http://www.chinaaccountingblog.com/weblog/untitled-text.html

[24] http://www.bloomberg.com/news/2011-03-14/china-mediaexpress-cfo-resigns-auditor-calls-for-investigation.html

[25] http://finance.yahoo.com/news/actinium-pharmaceuticals-inc-goes-public-192500100.html 